\title{
Austrogracilin A and B, two 2-naphthoic acid derivatives from the mushroom Austroboletus gracilis
}

\author{
Andrea Bartsch, Martin G. Bröckelmann, Bert Steffan, and Wolfgang Steglich* \\ Department Chemie, Ludwig-Maximilians-Universität, Butenandtstraße 5-13, \\ D-81377 München, Germany \\ E-mail: wos@cup.uni-muenchen.de
}

Dedicated to Professor Rodney W. Rickards on the occasion of his $70^{\text {th }}$ birthday

(received 10 Mar 04; accepted 08 Apr 04; published on the web 17 Apr 04)

\begin{abstract}
From air-dried fruit bodies of Austroboletus gracilis two unique naphthalene derivatives were isolated and their structures elucidated by spectroscopic and synthetic methods. The chemotaxonomic importance of these compounds is discussed.
\end{abstract}

Keywords: Austrogracalin, naphthalene derivatives, badione A

\section{Introduction}

Austroboletus gracilis (Peck) Wolfe, ${ }^{1}$ the Graceful Bolete, is a beautiful mushroom which belongs to a remarkable group of fungi with disjunct occurrence in Eastern North America and East Asia. ${ }^{2}$ It is widely distributed from Canada to Costa Rica and has also been recorded from Papua New Guinea, Japan, Taiwan, and China. In a preliminary investigation of this mushroom we have shown that badione $\mathrm{A}$ is responsible for the reddish-brown colour of its cap. ${ }^{3}$ In this communication we report on the isolation of two novel 2-naphthoic acid derivatives from this species.

\section{Results and Discussion}

Investigation of the methanol extract from air-dried fruit bodies of $A$. gracilis by HPLC with diode array-detection revealed the presence of two major constituents with very similar UV spectra. The two compounds, named austrogracilin A (1) and B (3), could be easily obtained pure by preparative HPLC on reversed phase. 
Austrogracilin A is a colourless solid, which becomes yellowish on standing in air. Its UV spectrum $(\mathrm{MeOH})$ exhibits absorption maxima at 229,266 , and $307^{\circ} \mathrm{nm}$, and in the IR spectrum intensive bands at $3392^{\circ}(\mathrm{OH}), 1686^{\circ}(\mathrm{C}=\mathrm{O})$, and $1243^{\circ}(\mathrm{OH}) \mathrm{cm}^{-1}$ are visible. The high resolution mass spectrum of austrogracilin A shows a molecular peak at $\mathrm{m} / \mathrm{z}^{\circ} 220.0369$ corresponding to the molecular formula $\mathrm{C}_{11} \mathrm{H}_{8} \mathrm{O}_{5}$.

The ${ }^{1} \mathrm{H}$ NMR spectrum $\left(\mathrm{CD}_{3} \mathrm{OD}\right)$ of austrogracilin A displays only three singlets at $\delta_{\mathrm{H}} 7.19$, $7.52(\mathrm{br})$, and $7.88(\mathrm{br})$ and a doublet at $\delta_{\mathrm{H}} 7.20(\mathrm{~J}=1.4 \mathrm{~Hz})$. According to the ${ }^{1} \mathrm{H},{ }^{1} \mathrm{H}-\mathrm{COSY}$ spectrum, the doublet arises by coupling with the proton responsible for the broadened signal at $\delta_{\mathrm{H}} 7.88$, thus indicating a meta-relationship. In addition, long-range couplings are observed which explain the broadening of the singlets at $\delta_{\mathrm{H}} 7.52$ and 7.88 .

The ${ }^{13} \mathrm{C}$ NMR spectrum of austrogracilin A exhibits 11 signals in the range between 100 and $175 \mathrm{ppm}$, in agreement with the molecular formula. In addition to signals for four aromatic $\mathrm{CH}$ groups at $\delta_{\mathrm{C}} 106.2,106.3,112.2$, and 122.5 , three quaternary aromatic $\mathrm{C}$-atoms at $\delta_{\mathrm{C}} 125.0$, 127.2 , and 131.5 are visible. Further signals at $\delta_{C} 149.0,149.5$, and 153.6 point to aromatic carbons carrying $\mathrm{OH}$ groups, and the signal at $\delta_{\mathrm{C}} 171.4$ can be assigned to a carboxyl group. HSQC and HMBC experiments allowed the assignment of all ${ }^{1} \mathrm{H}$ - and ${ }^{13} \mathrm{C}$-signals, and from the ${ }^{1} \mathrm{H},{ }^{13} \mathrm{C}$-correlations illustrated in Figure 1 the structure of a 4,6,7-trihydroxy-2-naphthoic acid (1) can be proposed for austrogracilin A. It is supported by strong NOE correlations between the two peri-protons at $\delta_{\mathrm{H}} 7.19$ and 7.88 in the NOESY spectrum.<smiles>[R20]c1cc2cc(C(=O)O)cc(O)c2cc1[R20]</smiles>

1, $\mathrm{R}=\mathrm{H}$

2, $\mathrm{R}=\mathrm{Me}$

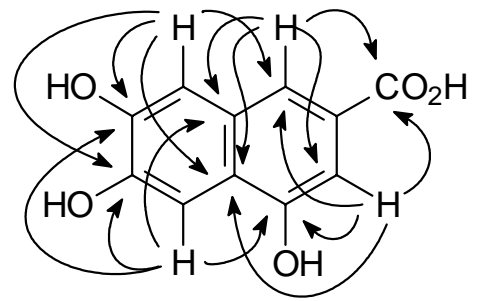

Figure 1. HMBC correlations of austrogracilin A (1).

4-Hydroxy-6,7-dimethoxy-2-naphthoic acid (2) is a known compound that can be prepared in three steps from veratraldehyde. ${ }^{4}$ Demethylation of 2 with $\mathrm{BBr}_{3}$ yielded 4,6,7-trihydroxy-2naphthoic acid, which was identical with the natural product.

The UV and IR spectra of austrogracilin A and B indicate a close structural similarity of both metabolites. The UV spectrum $(\mathrm{MeOH})$ of austrogracilin B exhibits absorption maxima at 221, 261 , and $323^{\circ} \mathrm{nm}$, and in the IR spectrum strong bands at 3458 and $3233^{\circ}(\mathrm{OH}), 1687(\mathrm{CO})$, and $1254^{\circ}(\mathrm{OH}) \mathrm{cm}^{-1}$ are visible. High resolution mass measurement of the $(\mathrm{M}-\mathrm{H})^{-}$peak at $\mathrm{m} / \mathrm{z} 247$ in the (-)-ESI MS led to the molecular formula $\mathrm{C}_{12} \mathrm{H}_{8} \mathrm{O}_{6}$ for austrogracilin $\mathrm{B}$. The ${ }^{1} \mathrm{H} \mathrm{NMR}$ spectrum $\left(\mathrm{CD}_{3} \mathrm{OD}\right)$ of austrogracilin $\mathrm{B}$ contains signals of four aromatic protons. Two of the signals appear as broadened singlets at $\delta_{\mathrm{H}} 8.43$ und 8.52 and one as doublet at $\delta_{\mathrm{H}} 8.60(\mathrm{~J}=1.3$ 
$\mathrm{Hz}$ ). The fourth aromatic proton gives rise to a sharp singlet at $\delta_{\mathrm{H}} 7.33$. In DMSO-d $\mathrm{d}_{6}$ additional signals for two phenolic protons at $\delta_{\mathrm{H}} 9.82$ and 10.29 are visible as well as a broad signal at $\delta_{\mathrm{H}}$ 12.92, which corresponds to two carboxyl protons. The ${ }^{1} \mathrm{H},{ }^{1} \mathrm{H}-\mathrm{COSY}$ spectrum indicates a strong correlation between the protons at $\delta_{\mathrm{H}} 8.52$ and 8.60 as well as long-range coupling between the protons at $\delta_{\mathrm{H}} 8.43$ and 8.52 . The ${ }^{13} \mathrm{C}$ NMR spectrum of austrogracilin B contains 12 signals. According to the DEPT NMR spectrum, the signals at $\delta_{\mathrm{C}} 109.9,112.8,129.0$, and 135.0 can be assigned to aromatic $\mathrm{CH}$-groups, whereas the signals at $\delta_{\mathrm{C}} 125.5,127.1,131.3,131.7$ belong to quaternary aromatic carbons. Two additional signals at $\delta_{\mathrm{C}} 148.8$ and 152.0 can be assigned to aromatic carbon atoms carrying $\mathrm{OH}$ groups, and signals at $\delta_{\mathrm{C}} 170.1$ and 171.2 point to the presence of two carboxyl groups. HSQC and HMBC experiments (Figure 2) allowed the assignment of all signals and established structure $\mathbf{3}$ for austrogracilin B. Like austrogracilin A, 3 shows a strong NOE effect between the two peri-protons in the NOESY spectrum.<smiles>[R]Oc1cc2cc(C([R])=O)cc(C([R])=O)c2cc1[R]</smiles>

3, $\mathrm{R}=\mathrm{H}$

$4, \mathrm{R}=\mathrm{Me}$

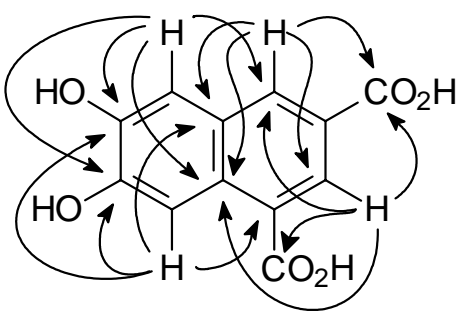

Figure 2. HMBC correlations of austrogracilin B (3).

Methylation of austrogracilin B (3) with diazomethane yielded the known permethyl derivative 4 . The latter has recently been obtained via an intriguing dimerization followed by oxidative cleavage of methyl 3,4-dimethoxycinnamate. ${ }^{5}$ The spectroscopic data from naturally derived $\mathbf{4}$ agree very well with those reported for the synthetic material.

\section{Conclusions}

The occurrence of the unique naphthalene derivatives $\mathbf{1}$ and $\mathbf{3}$ in Austroboletus gracilis underlines the special taxonomic position of this genus within the Boletineae. Before considering these compounds as chemotaxonomic markers, further species of Austroboletus have to be studied. In a recent phylogenetic investigation based on DNA analysis, Bresinsky and Binder ${ }^{6}$ found that Austroboletus gracilis, A. novae-zelandiae, and A. niveus form a genetically well defined group between Leccinum and Tylopilus. In contrast, Austroboletus betula (Schwein.) E. Horak, a North American species with yellow colours, belongs to a different clade including several Boletellus species. ${ }^{6}$ Therefore, the shift of A. betula from Boletellus to Austroboletus because of spore ornamentation ${ }^{1 \mathrm{~b}}$ appears not to be justified and should be reversed. This is also supported by the occurrence of variegatic acid, xerocomic acid, and atromentic acid in A. betula, 
pigments characteristic for the genus Boletellus. ${ }^{3,7}$ According to a preliminary investigation, ${ }^{8}$ most of the variegatic acid is present as a water-soluble sugar conjugate of undetermined constitution which is characterized by a $(\mathrm{M}-\mathrm{H})^{-}$ion at $\mathrm{m} / \mathrm{z} 1181$ in the negative ion FAB MS ${ }^{9}$ suggesting the presence of five hexose residues.

Since most of the Boletales pigments are biosynthetically derived from L-tyrosine, ${ }^{3}$ it is tempting to assume that this amino acid is also the precursor of the austrogracilins A (1) and B (3). On condensation of (3,4-dihydroxyphenyl)pyruvic acid with phosphoenol pyruvate, the naphthalenoid dihydroxydicarboxylic acid 5 could be formed, which might either lose two molecules of water to yield austrogracilin B (3), or undergo oxidation and dehydration to afford the quinone-methide 6 (Scheme 1). The latter could then deliver austrogracilin A (1) on decarboxylation. The possibility, however, that austrogracilin B (3) is formed by dimerization of 3,4-dihydroxycinnamic acid to a lignan with subsequent oxidative loss of a 3,4-dihydroxyphenyl residue cannot be excluded. A laboratory analogy for this process is available, ${ }^{5}$ and the common occurrence of thomasic acid and its degradation product 6-hydroxy-5,7-dimethoxy-2-naphthoic acid in Ulmus thomasii ${ }^{10}$ indicates that such reactions occur in nature.

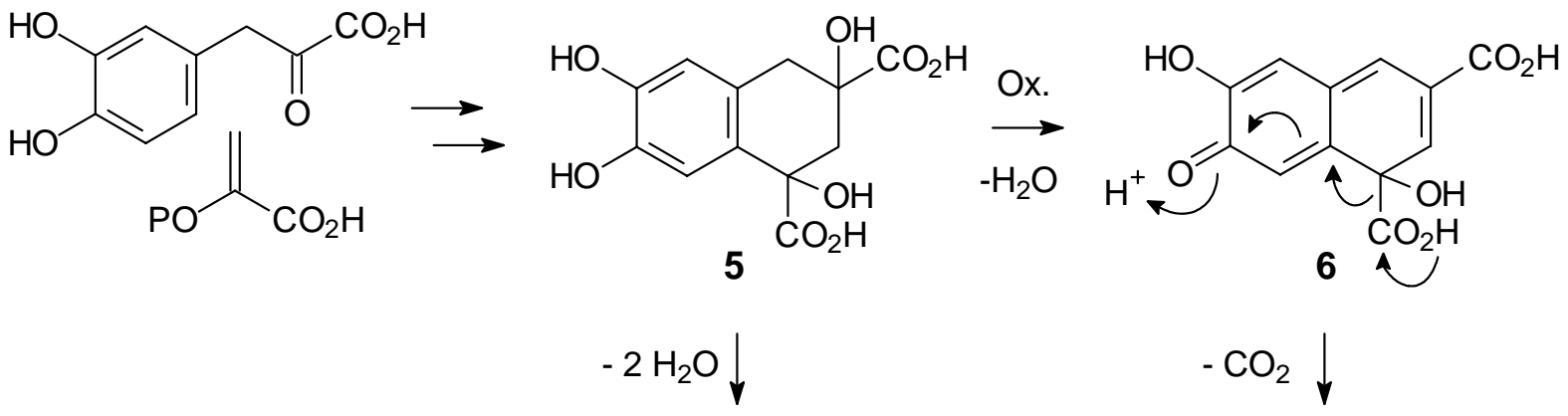

3

Scheme 1. Proposal for the biosynthesis of austrogracilin A (1) and B (3).

\section{Experimental Section}

General Procedures. Melting points (uncorrected): Leica Galen hot-plate. UV/Vis: PerkinElmer Lambda 16. IR: Perkin-Elmer FT-IR 1000. NMR: Bruker ARX-300 and AMX-600, with TMS or solvent peak as internal standard. MS: Finnigan MAT 90 and MAT 95Q $\left(70 \mathrm{eV}, 200^{\circ} \mathrm{C}\right.$ inlet temperature); MS (ESI): with a Finnigan API-Interface II. Solid phase extraction: Chromabond C18 cartridge, $0.5 \mathrm{~g}$ (Macherey and Nagel). TLC: Merck, silica gel $60 \mathrm{~F}_{254}$ or RP18 on aluminum foil, detection at 254 resp. $366 \mathrm{~nm}$. Gel chromatography: Sephadex LH-20 (Pharmacia). Analytical HPLC: Waters 510 pump and System Controller with Photodiode Array Detector 996, Knauer column $4 \times 250 \mathrm{~mm}$, Nucleosil $100 \mathrm{C} 18,5 \mu \mathrm{m}$. System 1: eluent A: $\mathrm{H}_{2} \mathrm{O} / \mathrm{CH}_{3} \mathrm{CN}$ 9:1 + 0.1\% TFA; eluent B: $\mathrm{CH}_{3} \mathrm{CN}$; linear gradient, 0 min: A 100\%, B 0\%; 25 min: 
A 50\%, B 50\%; flow rate $1^{\circ} \mathrm{mL} / \mathrm{min}$, detection range 200-400 $\mathrm{nm}$. System 2: same conditions as before, however, 0 min: A 100\%, B 0\%; 50 min: A 0\%, B 100\%. Preparative HPLC: Merck Hitachi L-6200 Intelligent Pump, 655A Variable Wavelength UV Monitor, Knauer column $20 \times$ $250 \mathrm{~mm}$, Nucleosil $100 \mathrm{C} 18,7 \mu \mathrm{m}$; system 3: eluent A: $\mathrm{H}_{2} \mathrm{O} / \mathrm{CH}_{3} \mathrm{CN}$ 9:1 + 0.1\% TFA; eluent B: $\mathrm{CH}_{3} \mathrm{CN}$; linear gradient, 0 min: A 100\%, B 0\%; $30 \mathrm{~min}$ : A 50\%, B 50\%; $55 \mathrm{~min}$ : A 50\%, B 50\%; flow rate $6.75^{\circ} \mathrm{mL} / \mathrm{min}$. All solvents for extraction or chromatography were distilled before use. $\mathrm{CH}_{2} \mathrm{Cl}_{2}$ was dried by distillation from Sicapent ${ }^{\mathrm{TM}}$ (Merck).

Fungal material. A. gracilis was collected in autumn 1994, 1996, 1997 in mixed hemlockrhododendron forests near Highlands, N.C., U.S.A. The fruit bodies were air-dried and stored at room temperature. Voucher samples are kept in the herbarium of N. Arnold, IPB, Halle/Saale.

Extraction and isolation procedure. The air-dried fruit bodies of A. gracilis (10 g) were pulverized, defatted with petroleum ether and then exhaustively extracted with degassed $\mathrm{MeOH}$ under an argon atmosphere in an ultrasound bath. The combined extracts were concentrated under reduced pressure and the residue distributed between water and EtOAc. The water phase was subsequently extracted with 2-butanol, and both organic phases were dried $\left(\mathrm{Na}_{2} \mathrm{SO}_{4}\right)$ and concentrated in vacuo. After solid-phase extraction of the combined residues on a RP-18 cartouche, the compounds were separated by preparative HPLC (system 3). The resulting fractions were lyophilized to yield austrogracilin A (1) (14 mg, 0.14\% of dry-weight) and austrogracilin B (3) (15 mg, 0.15\% of dry-weight).

Austrogracilin A (4,6,7-trihydroxy-2-naphthoic acid) (1). $\mathrm{Mp}>190{ }^{\circ} \mathrm{C} \mathrm{dec}$; TLC: $R_{f} 0.33$ $\left(\mathrm{SiO}_{2}\right.$, toluene $/ \mathrm{HCO}_{2} \mathrm{Et} / \mathrm{HCO}_{2} \mathrm{H}$ 10:5:3), $0.70\left(\mathrm{RP}-18, \mathrm{MeOH}+2\right.$ drops of TFA); HPLC: $t_{\mathrm{R}} 10.0$ min (system 1), $13.6 \mathrm{~min}$ (system 2); UV-vis (MeOH) $\lambda_{\max }(\log \varepsilon) 205$ (sh, 3.74), 229 (4.04), 261 (4.20), 266 (sh, 4.19), 307 (3.53), 316 (sh, 3.51), 349 (sh, 2.87) nm; IR (KBr) v 3392 (s, br), 2926 (m), 2854 (m), 1686 (s), 1632 (m), 1617 (m), $1594(\mathrm{~m}), 1540$ (m), 1499 (m), 1410 (s), 1243 (s), 1201 (s), 1159 (m), 1108 (m), $1056(\mathrm{~m}), 956(\mathrm{w}), 894(\mathrm{~m}), 866(\mathrm{~m}), 775(\mathrm{~m}), 717$ (m), 626 (m) $\mathrm{cm}^{-1} ;{ }^{1} \mathrm{H}$ NMR (300 MHz, CD $\left.{ }_{3} \mathrm{OD}\right) \delta 7.19$ (s, $\left.1 \mathrm{H}, \mathrm{H} 8\right), 7.20$ (d, $1 \mathrm{H}, J=1.4 \mathrm{~Hz}, \mathrm{H} 3$ ), 7.52 (br s, $1 \mathrm{H}, \mathrm{H} 5), 7.88$ (br s, $1 \mathrm{H}, \mathrm{H1}$ ); ${ }^{13} \mathrm{C} \mathrm{NMR}$ (151 MHz, CD $\left.\mathrm{OD}\right) \delta 106.2$ (C5), 106.3 (C3), 112.2 (C8), 122.5 (C1), 125.0 (C4a), 127.2 (C2), 131.5 (C8a), 149.0 (C7), 149.5 (C6), 153.6 (C4), $171.4\left(\mathrm{CO}_{2} \mathrm{H}\right)$; MS (EI) m/z (rel intensity) $220\left(\mathrm{M}^{+}, 100 \%\right), 203$ (10), 191 (6), 175 (12), 163 (4), 147 (11); HRMS (EI): found $\mathrm{M}^{+} 220.0369, \mathrm{C}_{11} \mathrm{H}_{8} \mathrm{O}_{5}$ requires 220.0372.

Austrogracilin B (6,7-dihydroxy-2,4-naphthalene dicarboxylic acid) (3). $\mathrm{Mp}>250{ }^{\circ} \mathrm{C} \mathrm{dec}$; TLC: $R_{f} 0.26\left(\mathrm{SiO}_{2}\right.$, toluene $\left./ \mathrm{HCO}_{2} \mathrm{Et} / \mathrm{HCO}_{2} \mathrm{H} 10: 5: 3\right), 0.75$ (RP-18, $\mathrm{MeOH}+2$ drops of TFA); HPLC: $t_{\mathrm{R}} 11.2 \mathrm{~min}$ (system 1); UV-vis (MeOH) $\lambda_{\max }(\log \varepsilon) 205$ (sh, 4.27), 208 (sh, 4.30), 214 (sh, 4.32), 221 (4.35), 261 (4.63), 323 (3.91), 348 (sh, 3.81) nm; IR (KBr) v 3458 (s), 3233 (m), $1687(\mathrm{~s}), 1642$ (m), $1534(\mathrm{~m}), 1477$ (m), 1432 (m), 1382 (m), 1254 (s), $1229(\mathrm{~m}), 1200(\mathrm{~m}), 1144$ (m), $1010(\mathrm{w}), 923(\mathrm{w}), 871(\mathrm{~m}), 794(\mathrm{w}), 766(\mathrm{w}), 736(\mathrm{w}), 671(\mathrm{w}), 657(\mathrm{w}), 626(\mathrm{~m}), 593(\mathrm{w})$, 554 (w) cm ${ }^{-1} ;{ }^{1} \mathrm{H}$ NMR (300 MHz, CD $\left.{ }_{3} \mathrm{OD}\right) \delta 7.33$ (s, $1 \mathrm{H}, \mathrm{H} 8$ ), 8.43 (br s, $1 \mathrm{H}, \mathrm{H} 5$ ), 8.52 (br s, $1 \mathrm{H}, \mathrm{H} 1), 8.60$ (d, $1 \mathrm{H}, J=1.3 \mathrm{~Hz}, \mathrm{H} 3) ;{ }^{1} \mathrm{H}$ NMR (600 MHz, DMSO-d 6 ) $\delta 7.35$ (s, $\left.1 \mathrm{H}\right), 8.33$ (s, $1 \mathrm{H}), 8.38$ (d, $J=1.6 \mathrm{~Hz}, 1 \mathrm{H}), 8.44$ (br d, $J=0.8 \mathrm{~Hz}, 1 \mathrm{H}), 9.82$ (br s, $1 \mathrm{H}, \mathrm{OH}), 10.29$ (br s, 1 
$\mathrm{H}, \mathrm{OH}), 12.92\left(\right.$ br s, $\left.2 \mathrm{H}, 2 \times \mathrm{CO}_{2} \mathrm{H}\right) ;{ }^{13} \mathrm{C} \mathrm{NMR}\left(151 \mathrm{MHz}, \mathrm{CD}_{3} \mathrm{OD}\right) \delta 109.9$ (C5), 112.8 (C8), 125.5 (C2), 127.1 (C4), 129.0 (C3), 131.3 (C8a), 131.7 (C4a), 135.0 (C1), 148.8 (C7), 152.0 (C6), $170.1\left(2 \times \mathrm{CO}_{2} \mathrm{H}\right), 171.2\left(4-\mathrm{CO}_{2} \mathrm{H}\right) ; \mathrm{MS}(\mathrm{ESI}) \mathrm{m} / \mathrm{z}$ (rel intensity) $495(2 \mathrm{M}-\mathrm{H})^{-}, 247(\mathrm{M}-$ $\mathrm{H})^{-}$, HRMS [(-)-ESI]: found $(\mathrm{M}-\mathrm{H})^{-} 247.0243, \mathrm{C}_{12} \mathrm{H}_{7} \mathrm{O}_{6}{ }^{-}$requires 247.0243 .

Demethylation of synthetic 4-hydroxy-6,7-dimethoxy-2-naphthoic acid (2). To a supension of $2^{4 \mathrm{a}}(497 \mathrm{mg}, 2.0 \mathrm{mmol})$ in dry $\mathrm{CH}_{2} \mathrm{Cl}_{2}(20 \mathrm{~mL})$ was added at $-78^{\circ} \mathrm{C}$ a solution of $\mathrm{BBr}_{3}(1.50 \mathrm{~g}$, $580 \mu \mathrm{l}, 6.0 \mathrm{mmol})$ in dry $\mathrm{CH}_{2} \mathrm{Cl}_{2}(10 \mathrm{~mL})$. After stirring at the same temperature for $30 \mathrm{~min}$, the cooling bath was removed and the stirring was continued for $12 \mathrm{~h}$. The mixture was quenched with water and the aqueous phase extracted with 2-butanol. The organic extracts were concentrated in vacuo, and the brown solid residue was purified by preparative HPLC on RP-18 (system 3) to yield 4-hydroxy-6,7-dimethoxy-2-naphthoic acid (1) (400 mg, 91\%) as a colourless solid, which rapidly turned brown. All physical and spectroscopic data were in agreement with those of austrogracilin A.

Permethylation of Austrogracilin B. A solution of diazomethane in $\mathrm{Et}_{2} \mathrm{O}$ was added dropwise at $0{ }^{\circ} \mathrm{C}$ to a stirred mixture of $3(5 \mathrm{mg}, 0.02 \mathrm{mmol})$ and silica gel $(50 \mathrm{mg})$ in $\mathrm{MeOH}(5 \mathrm{~mL})$ until the gas evolution stopped. The stirring was continued for $30 \mathrm{~min}$, the cold bath removed and the excess of diazomethane destroyed by addition of acetic acid. Then, the solution was evaporated and the residue distributed between water and EtOAc. The dried $\left(\mathrm{Na}_{2} \mathrm{SO}_{4}\right)$ organic solution was concentrated in vacuo and the residue purified by TLC on silica gel with hexanes/EtOAc 1:1. Dimethyl 6,7-dimethoxy-2,4-naphthalene dicarboxylate (4) (5 $\mathrm{mg}, 82 \%)$ was obtained as a colourless solid. $\mathrm{Mp} 159-161{ }^{\circ} \mathrm{C} \quad\left[\mathrm{lit}^{5} \mathrm{mp} 134-136{ }^{\circ} \mathrm{C}(\mathrm{MeOH})\right]$; TLC: $R_{f} 0.76 \quad\left(\mathrm{SiO}_{2}\right.$, hexanes/EtOAc 1:1); UV (MeOH) $\lambda_{\max }(\log \varepsilon) 210$ (4.33), 219 (4.34), 262 (4.59), 318 (3.90), 333 (sh, 3.83), $352 \mathrm{~nm}(\mathrm{sh}, 3.68) \mathrm{nm}$; IR (KBr) v $3436(\mathrm{~s}), 2962$ (m), $2924(\mathrm{~m}), 2854(\mathrm{~m}), 1708(\mathrm{~s})$, 1624 (m), 1580 (m), 1509 (m), 1484 (m), 1434 (m), 1375 (m), 1332 (m), 1295 (m), 1262 (m), 1195 (m), 1141 (m), 1105 (s), 1029 (s), 1013 (m), 993 (m), 906 (w), 867 (m), 861 (m), 801 (m), $765(\mathrm{~m}), 709(\mathrm{~m}), 573(\mathrm{w}) \mathrm{cm}^{-1}$; ${ }^{1} \mathrm{H}$ NMR $\left(600 \mathrm{MHz}, \mathrm{CDCl}_{3}\right) \delta 3.99,4.01,4.03,4.08$ (each s, 3 $\left.\mathrm{H}, \mathrm{CH}_{3}\right), 7.24(\mathrm{~s}, 1 \mathrm{H}), 8.55(\mathrm{~s}, 1 \mathrm{H}), 8.61(\mathrm{~d}, J=1.6 \mathrm{~Hz}, 1 \mathrm{H}), 8.71(\mathrm{~d}, J=1.6 \mathrm{~Hz}, 1 \mathrm{H}) ;{ }^{13} \mathrm{C}$ NMR (151 MHz, $\left.\mathrm{CDCl}_{3}\right) \delta$ 52.2, 52.3, 55.9, $56.1\left(\right.$ each $\left.\mathrm{CH}_{3}\right), 104.9(\mathrm{CH}), 107.8(\mathrm{CH}), 124.5$ $\left(\mathrm{C}_{\mathrm{q}}\right), 124.8\left(\mathrm{C}_{\mathrm{q}}\right), 128.5(\mathrm{CH}), 129.5\left(\mathrm{C}_{\mathrm{q}}\right), 130.5\left(\mathrm{C}_{\mathrm{q}}\right), 134.0(\mathrm{CH}), 150.0\left(\mathrm{C}_{\mathrm{q}}\right), 152.9\left(\mathrm{C}_{\mathrm{q}}\right), 166.7$ $\left(\mathrm{C}_{\mathrm{q}}\right), 167.7\left(\mathrm{C}_{\mathrm{q}}\right)$; GC/MS (EI) m/z (rel intensity) $304\left(\mathrm{M}^{+}, 100 \%\right), 273$ (50), 230 (12); HRMS (EI) found $\mathrm{M}^{+}$304.0936, $\mathrm{C}_{16} \mathrm{H}_{16} \mathrm{O}_{6}$ requires 304.0947.

\section{Acknowledgements}

We thank Dr. N. Arnold, IPB Halle/Saale, for his kind assistance in collecting the fungi. The generous hospitality and assistance of the Highlands Biological Station, Highlands, N.C., USA, is gratefully acknowledged. This research was supported by the Deutsche Forschungsgemeinschaft and the Fonds der Chemischen Industrie. 


\section{References}

1. (a) Wolfe, C. B., Jr. Austroboletus and Tylopilus subgenus Porphyrellus. Bibl. Mycol. 69; J. Cramer: Vaduz, 1979. (b) Horak, E. Sydowia 1980, 33, 71. (c) Bessette, A. E.; Roody, W. C.; Besette, A. R. North American Boletes; Syracuse University Press, 2000.

2. Wu, Q.-X.; Mueller, G. M. Can. J. Bot. 1997, 75, 2108.

3. Gill, M.; Steglich, W. Progr. Chem. Org. Nat. Prod. 1987, 51, 59.

4. (a ) El-Assal, L. S.; El-Wahhab, S. A. M. J. Chem. Soc. 1960, 849. (b) Harper, S. H.; Kemp, A. D.; Tannock, J. J. Chem. Soc. C 1970, 626.

5. Pelter, A.; Ward, R. S.; Venkateswarlu, R.; Kamakshi, C.; Moinuddin, S. G. A.; Subhash, P. V.; Hursthouse, M. B.; Coles, S. J.; Light, M. E. Tetrahedron 2001, 57, 7755.

6. Binder, M. Ph.D. Thesis, University of Regensburg, 1999.

7. Bresinsky, A.; Besl, H. Z. Mykol. 1979, 45, 247.

8. Bröckelmann, M. G.; Steglich, W. Unpublished results.

9. Glycosides of variegatic acid have also been discovered in the North American Boletus morrisii: Herrmann, R. Ph.D. Thesis, University of Bonn, 1980.

10. Chen, C.-L.; Hostettler, F. D. Tetrahedron 1969, 25, 3223. 